\title{
Jasna Vince \\ IMENICE MUŠKOGA RODA (J)A-DEKLINACIJE U HRVATSKOM CRKVENOSLAVENSKOM I STAROHRVATSKOM JEZIKU
}

\author{
Izvorni znanstveni rad \\ Original scientific paper
}

\section{UDK 811.163.1'366.521}

\begin{abstract}
U radu se opisuju morfološke, sintaktičke i semantičke osobitosti imenica muškoga roda (j)a-deklinacije u hrvatskom crkvenoslavenskom i starohrvatskom jeziku. Za razliku od ostalih imenica (j)a-deklinacije one uvijek ukazuju na (mušku) osobu, pa nije neobično što u njihovoj sklonidbi uz oblike (j)a-deklinacije nerijetko nalazimo i dublete: oblike (j)o-deklinacije. Autorica bilježi zanimljivosti i kolebanja u sročnosti - po rodu i živosti - pridjevnih riječi s promatranim imenicama te ukazuje na ulogu što je pripadnost muškomu rodu unutar (j)a-deklinacije ima pri odabiru padeža zanijekanoga izravnoga objekta i u odabiru oblika za vokativ jednine te u tvorbi posvojnoga pridjeva.
\end{abstract}

Ključne riječi: hrvatski crkvenoslavenski jezik, starohrvatski jezik, (j)a-deklinacija, muški rod, sročnost, morfologija, sintaksa, semantika

\section{Uvod}

O imenicama muškoga roda (j)a-deklinacije - koja obuhvaća tvrde i meke osnove - u hrvatskom crkvenoslavenskom jeziku govorit ćemo kao o zasebnoj skupini, ali ne zbog njihove sklonidbe - koja se ne razlikuje od sklonidbe ostalih imenica te skupine, dakle od sklonidbe imenica ženskoga roda' (voevoda se sklanja jednako kao voda, a ûnoša kao duša) - nego zahvaljujući tomu što pridjevi, participi i pridjevne zamjenice uz njih dobivaju nastavke muškoga roda: našb voevoda, ûnoša, ali naša voda, duša - i tako u svim padežima. ${ }^{3}$ To je pak sintaktičko svojstvo posljedak semantičke sastavnice tih imenica: 'osoba muškoga spola'. Prirodni se rod dakle u njih označuje sintaktički, ali ne i morfološki.

Imenice koje su predmetom ovoga rada dvovrsne su. Samo prve imenuju isključivo muške osobe:4 papa, velmoža itd., a druge - o kojima se u literaturi govori kao o imenicama općega

\footnotetext{
U nastavku će se ipak pokazati neke razlike proizišle iz samostalnih putova kojima su imenice muškoga roda (j)a-deklinacije krenule kako bi se oblikom približile imenicama istoga roda (j)o-deklinacije.

2 Hrvatskocrkvenoslavenski su primjeri preuzeti iz građe za Rječnik crkvenoslavenskoga jezika hrvatske redakcije koji se izrađuje u Staroslavenskom institutu u Zagrebu. Popis i opis izvora nalaze se u Rječniku (2000: XXXI-XXXVI). Glagoljična slova prenose se u latinicu onako kako je uobičajeno u najnovijim izdanjima Staroslavenskoga instituta. 3 Neki pridjevni i zamjenički padežni oblici s potpunom neutralizacijom - kao npr. A mn.: naše voevodi = naše sestri - ne umanjuju vjerodostojnost te tvrdnje jer je sinkretizam u jeziku obična pojava.

4 "Te imenice označuju m. osobe zbog bioloških, društvenih i jezičnih razloga; bioloških zato što označuju osobe m. spola (djeda, tata...), društvenih zato što su nosioci tih značenja, uglavnom zanimanja, bili samo muškarci (dahija, drvodjelja, šeširdžija...), jezičnih zato što je tako uobičajeno (tradicija), što uza se imaju mocijsku tvorbu (sluga-sluškinja, kolega-kolegica...)" (Babić 1998: 26).
} 
roda (Tafra 2005: 86) - odnose se na oba spola: ûnošica, lûbodêica, bližika itd. 5 Dokje, dakle, u prvih rod uvijek muški, u drugih je promjenjiv.

Među imenicama ja-deklinacije obaju rodova ima i onih koje u nominativu jednine osim na -ê (fonološki ja) mogu završavati i na -i, npr. ml'ni/m/'nii ml'niê f. U praksi se stoga u nedostatku oblika za N jd. uspostavlja oblik koji se može rekonstruirati na temelju staroslavenskih primjera. Tako je primjerice u prvom svesku Rječnika crkvenoslavenskoga jezika hrvatske redakcije riječ koja znači 'vrač, liječnik' obrađena pod natuknicom: balii, -ie m. iako nema nijedne potvrde za N jd. koja bi upućivala na takvo rješenje: sve su odreda u ostalim padežima (2000: 110). Nedoumice oko imenica na -i ne prestaju, međutim, ni onda kada nam je N jd. poznat: sudii. Budući da se grafički zapis ii dade interpretirati ne samo kao fonološki slijed iji nego i ij, jasno je da se u osnovâ koje u ostalim padežima iskazuju promjenjivu paradigmatsku pripadnost: čas jo-deklinaciji, čas ja-deklinaciji (v. 4. odjeljak) nominativ jednine ne može sa sigurnošću pripisati nijednomu od tih dvaju deklinacijskih tipova.

U odostražnom popisu imenica iz građe za Rječnik crkvenoslavenskoga jezika hrvatske redakcije 6 naći ćemo jedno formalno obilježje koje već na prvi pogled odaje pripadnost dotičnih imenica ja-deklinaciji i muškome rodu: završetak -čii i -čiê. U njemu se prepoznaje stari turkijski sufiks ${ }^{7}$ koji je u suvremenom hrvatskom jeziku i danas produktivan, a ostvaruje se - glasovno najčešće ponešto promijenjen - u riječima: ćurčija, buregdžija, samardžija, kamiondžija, galamdžija i sličnima. I tu i tamo imenice označuju muškarca s određenim zanimanjem ili osobinom.

Slijede primjeri (1)-(5) imenicâ muškoga roda ja-deklinacije s potvrđenim ili bar mogućim nominativom jednine na -i. Njima valja pribrojiti imenice kojih su oblici potvrđeni u 4. odjeljku, a normiraju se dvojako - kao imenice ja-deklinacije: sudii, -ie m., ${ }^{8}$ ali i kao imenice meke inačice o-deklinacije, dakle jo-deklinacije: sudii, -iê m. (kao netii, -iê m).

(1) G jd:: glasb guslbnikь i musikie i pis'čie i truba ne imat' slišana biti BrVO 278b

(2) N mn.: ruku prostrêše na srebro êk(o) skud'ni i h'leb'čie PsFr 101a

(3) N jd.: edinь hlêbar' a drugi čbvınьči BrVO 178b

(4) N jd.: pogibe toliko bogatbstvo i vsьk' kr'mčii BrVO 278a

(5) N mn.: v'lažahu balie i vl'svi BrvO 443a

I na kraju, sve ostale imenice - kojih nije malen broj9 - imaju nastavak -a: lûbodêica, p'ênica, prêdaica, ûnošica, razboica, uboica, ubiica, mužeubiica, človêkoubiica, plıtoubiica, starê(i)šina, starina, bližika, užika, vladika, velmoža, sluga, sirota, ûnota, ûnoša, voevoda, mesiê, papa, evanjelista, patriêrha, varnava/barnaba, an'na, tobiê, ananiê, isaiê, kaêpa/kaifa, iliê i brojne druge. Neki su sufiksi razmjerno česti, a ima i posuđenica, među kojima su najzastupljenija osobna imena.

Upućujem i na otklone od suvremenoga hrvatskoga. Tako se u hrvatskom crkvenoslavenskom umjesto očekivane riječi ja-deklinacije prêd'teča m. pojavljuje riječ prêd'tečb m., i to mnogo puta, dok je s druge strane naš vođa u promatranoj građi bogato potvrđen kao imenica jo-promjene - voždb:

(6) N jd:: prêd'tečs g(ospodb)nь pride $\mathrm{BrN}_{2} 434 \mathrm{a}$

(7) N mn.: s(i)nove iže bêhu iz' tvrdi bêhu imb voždi BrVO 206c

Pogledajmo sada po kojim se to sintaktičkim - a katkada i morfološkim - crtama imenice muškoga roda (j)a-deklinacije ne uklapaju među ostale imenice te deklinacije. Njihova je semantička posebnost već istaknuta. Težište je na slici koju pružaju tekstovi pisani hrvatskocrkvenoslaven-

\footnotetext{
5 Neki "takve imenice nazivaju i dvorodovnima (...), pa se čak govori o dva leksema, rus. sirota $($ m) i sirota 2 (ž) (...)" (Tafra 2005: 86).

$6 \quad$ Izradila ga je Vjera Lopina.

7 Takvo gledanje u literaturi prevladava, o čemu više u Cejtlin (1977: 124-125). Imenicama te tvorbe u hrvatskoglagoljskim tekstovima posvećen je rad Sandre Sudec (2009), iz kojega je preuzet i dio primjera.

8 U starocrkvenoslavenskom jeziku ta imenica pripada isključivo ja-promjeni (Slovník, IV: 397).

9 Već u najstarijim hrvatskoglagoljskim fragmentima zabilježene su sljedeće: varısava, toma, setena, iûna, iûda, vladika, luka, an'na, kaêpa, agripa, kuzma, ananiê, jeorjîe, oziê, manasiê, osiê, matiê (Mihaljević 2004: 625-626).
} 
ski, a starohrvatski podatci poslužit će nam kao pomoćno sredstvo za njezino osvjetljavanje.10 Poznato je, naime, da je hrvatski crkvenoslavenski jezik bio pod jakim utjecajem onodobnih hrvatskih govora, najviše čakavskih.

\section{Sročnost po rodu}

Sročnost po rodu možemo pratiti u jednini, dvojini i množini. U jednini je u imenica muškoga roda (j)a-deklinacije provedeno slaganje po smislu, pa će atributni oblici za ženski rod upućivati na to da je riječ o imenicama općega roda, kao u sljedećim primjerima s imenicama bližika i užika:

(8) N jd.: raguilb bližika tvoi BrVat 204 c / užika tvoi BrN 222C

(9) N jd.: D jd.: drugi bratb ili b'ližika primetb ženu ego da v'stavil' bi sême bratu ili b'ižiki s'voemu BrN 389 b

(10) N jd.: elisav(e)ta bližika tvoê BrN $2444 c$ / elisav(e)ta užika tvoê BrVat ${ }_{19} 310 d$

U množini se susrećemo sa slaganjem po smislu, kao u (11): pridjev s provedenom drugom palatalizacijom ispred -i u nominativu množine nedvosmisleno svjedoči o muškom rodu, ali primjer (12) pokazuje da može nastupiti i slaganje po obliku (usp. vsi otroci vse starêšini), koje u našoj građi prevladava. Pritom se razlikovanje muškoga i ženskoga roda u imenica (j)a-promjene u množini zatire (vse starêšini kao vse ženi):

(11) N mn.: kupci tvoi bêahu velmože z(e)ml'sci BrVO 278b

(12) N mn.: vsi otroci paraonovi i vse starêšini BrvO 182a

U suvremenom hrvatskom jeziku prva je mogućnost češća i običnija i sve više uzima maha,11 dok su u jeziku starih čakavskih pisaca obje ravnomjerno raspoređene. ${ }^{12}$ Promjena roda koja je pogodila imenice muškoga roda (j)a-deklinacije u množini, tj. njihov prelazak u ženski rod, zauzima značajno mjesto u tipologiji slavenskih rodova i mnogi je autori ističu kao neobičnu ( $\mathrm{V}$. Naylor 1988; Corbett 1988).

Vratimo se jednini. Za razliku od množine - u kojoj je uobičajeno kolebanje između sročnosti po smislu: vsi slugi i po obliku: vse slugi (ali, rekli smo, drugo rješenje preteže) - tom je broju svojstveno slaganje po smislu, kao u primjerima (13), (14) i (15): sluga moi, lihoim'šago sotoni, sotona samb, sotona razdêlen:

(13) N jd.: idêže azb es(b)mb tu sluga moi budetb $\mathrm{BrN}_{2} 333$ / sluga moể

(14) G jd:: ot lihoimav'šago sotoni PsFr 117a

(15) N jd:: sotona samb v' s(e)bê razdêlen' e(stb) MRoč 37a / sotona sama v sebê razdêlen'est' MVat $44 d$

Druga inačica u primjeru (13): sluga moê posve je neočekivana i zato snažno stilski obojena.14 To vrijedi i za oblik sama uz riječ sotona (15). ${ }^{15}$ Iz posljednjeg se primjera (iz njegove druge inačice) dade iščitati još jedno pravilo sročnosti. Tu se glagolski pridjev u predikatu slaže s imenicom po smislu, a kvantifikator prema obliku: usp. ženski rod: sama prema muškom rodu: razdêlen'16 Ta

\footnotetext{
10 Izvori: Maretić 1885; Zima 1887; Rešetar 1894; Glavan 1928/29.

11 Usp. VINCE 2004: 109 (bilj. 8).

12 "Kad imenice navedene u toč. a., c. i d. stoje u pl., uzimaju se sad kao masc., a sad opet kao fem." (GLAVAN 1928/29: 117). Na istoj stranici navedeni su s jedne strane primjeri za slaganje po smislu, npr.: Vojvode Davidovi obsedoše ga, a s druge za slaganje po obliku, kao ovaj: Tebe sluge moje učeći vapiše. Među rečenicama koje autor navodi ima i onih koje ništa ne dokazuju jer je u njima akuzativ množine, a taj je padež, kako znamo, za muški i ženski rod jednak i u pridjeva i u zamjenica.

13 Primjer je iz Drugoga ljubljanskoga (beramskoga) brevijara - 109c (Mihaljević, ovdje).

14 Ipak, takva sročnost nije strana tekstovima pisanima starim hrvatskim jezikom. Glavan tako donosi tri primje-

ra, od kojih jedan glasi: Da vidite još rvanje od Lovrinca božje sluge. (Glavan 1928/29: 116).

15 Tu se očituje razlika između bliže i dalje sročnosti (Babić 1998: 13).

16 "attributive < predicate < relative pronoun < personal pronoun" (Corbett 1988: 14).
} 
se zakonitost dade potpunije izraziti pomoću "ljestvice sročnosti"17 u kojoj je predikat s obzirom na sklonost prema slaganju po obliku smješten iza atributa, ali ispred odnosne i lične zamjenice. To znači da je vjerojatnost sročnosti po smislu u predikata veća nego u atributa (što potvrđuje i naš primjer), ali manja nego u nabrojenih zamjenica.

Pogledajmo još kakvo je stanje u dvojini, za koju - dakako - nema mnogo potvrda. Zabilježena je sročnost po obliku (16) i sročnost po smislu (17):

(16) A dv:: i obrêza ... b.i. (=12) starêšinê otbčbscê BrvO 264a

(17) N dv:: siê êko starêišinê kolênu velika ... pomišal'ša i ne vêrovav'ša b(og)u PsFr 94b

U starocrkvenoslavenskom je u jednini sročnost po smislu, u dvojini i množini dopunske se riječi obično slažu s imenicom po obliku, ali u množini ima i slaganja po smislu (Damjanović 2005: 159).

Daljnji je korak u približavanju imenica muškoga roda (j)a-sklonidbe "matičnoj" sklonidbi imenica muškoga roda: (j)o-sklonidbi - po kojoj se, uostalom, sklanjaju i pridjevi muškoga roda - unošenje njezinih oblika u svoju paradigmu.18 Dobit ćemo tako miješanje padeža obiju deklinacija, kao što pokazuju primjeri iz 4. odjeljka.19

\section{Sročnost po živosti}

Uz imenice muškoga roda koje označuju živo, pridjevi (uključujući i zamjeničke) u akuzativu jednine, kao što je poznato, dobivaju genitivni nastavak. Pravilo se primjenjuje i na same imenice ukoliko pripadaju (j)o-sklonidbi. U imenica muškoga roda (j)a-deklinacije pridjev je, međutim, jedini - sintaktički - pokazatelj živosti (kao i roda), za razliku od imenica istoga roda (j)o-deklinacije u kojih se rod razabire i iz same imeničke paradigme. ${ }^{20}$ Razvidno je to iz sljedećih primjera:

(18) A jd:: pom(i)lui raba tvoego papu n(a)š(e)go BrVO 151c

(19) A jd.: vidêše ûnošu sêdeĉa o desnoû odêna v' odêû bêlu MVat $110 \mathrm{~b}$

Zamisliva su tri tipa otklona od "kanonskoga" stanja prikazanoga u primjerima (18) i (19). Prvi je neutralizacija slična onoj koju zapažamo u drugoj inačici primjera (13) u N jd.: sluga moê kao sestra moê, dakle A jd.: slugu moû kao sestru moû. S druge bismo strane mogli očekivati suprotnu težnju - širenje genitivnoga oblika za sintaktički akuzativ i na samu imenicu, kojoj bi se oblik mogao ostvariti na dva načina.

Razmotrimo prvi. On bi nastao "križanjem" prvotne (j)a-osnove i nastavka (j)o-osnove, kao u

17 Usp. sljedeće zapažanje: "U kajkavštini ne samo što uz takve samostavnike pridavničke riječi ne primaju oblika ženskoga roda, nego kad kad i sam samostavnik mijeńa ženski oblik prelazeći u deklinaciju riječi muškoga roda" i primjer: Pri kom je Andro Kralević? Pri jednom bašu (Zima 1887: 185).

18 Ima govora - kao što je vodički (u Istri) - u kojima je priklanjanje imenica muškoga roda (j)a-deklinacije (j)o-deklinaciji sustavno provedeno (ali samo u množini): "Zanimljivo je da se te imenice (kao u imenskoj skupini naš starišina, op. J. V.), u pluralu ne samo slažu nego i sklanjaju kao imenice muškoga roda: ... naši starišini ..." (Ribarić 2002: 146). Tako je i u (vodičkomu govoru zemljopisno bliskom) slovenskome jeziku: naš vojvoda - naši vojvodi (Ivić 1968: 54).

19 "Posebno su poglavlje imenice muškoga roda $a$-sklonidbe. lako njihov akuzativ nije sinkretičan s genitivom, pridjev - predikatni proširak jest (...) Po ugledu na ostale imenice muškoga roda za živo i ovima se predikatni proširak u akuzativu pogenitivio. Presudan je dakle sadržaj imenica $a$-sklonidbe ('živo'), a ne njihov oblik. U staroslavenskom je jeziku doseg živosti uži, pa uz te imenice nalazimo i negenitivne oblike za akuzativ kao na pr. u Marijinskom evanđelju (...) sêdęštı i odênъ" (Vince Marinac 1992/93: 391). Genitivnim oblicima za akuzativ (sêdeĉa, odêna), kao i onima koji nisu izjednačeni s genitivom: akuzativnima (sêdęštb) i nominativno-akuzativnima (odênъ) zajedničko je prenošenje obavijesti o muškom rodu. Akuzativ bi tih pridjeva i participa uz imenice ženskoga roda iste paradigme glasio: sêdeĉu, odênu.

20 To je posljednji korak u razvitku genitivno-akuzativnoga sinkretizma za živo u muškom rodu u jednini. Na stupnju koji mu je prethodio genitivni oblik za akuzativ za izricanje živosti uvele su imenice u-deklinacije i $i$-deklinacije. I one su taj oblik preuzele iz (j)o-deklinacije; usp. A jd.: sina, gosta kao človêka, a ne: *sinu, * gosti - kako glase genitivi jednine imenica s u-osnovom i i-osnovom. Usp. Klenin 1983: 83-84. 
Ajd.: sluga moego. Prisjetimo li se onoga što je rečeno u prethodnom odjeljku o prodiranju oblika (j)o-deklinacije u (j)a-deklinaciju imenica muškoga roda, nećemo se začuditi što takvih primjera doista ima; usp. prvu inačicu A jd. u (30): sudiê. Poznaje ih i stari hrvatski jezik, kako pokazuje primjer iz Ranjinina lekcionara:

(20) A jd.: stvarajući mene iz utrobe sluga sebje

U navedenim su primjerima - (20) i (30) - imenice (j)a-promjene sudiê i sluga pristupile imenicama (j)o-deklinacije te su - poput ostalih imenica te deklinacije koje označuju živo - u akuzativu poprimile genitivni oblik; usp. A jd.: sudiê, sluga kao netiê, vraga. ${ }^{21}$

Posljednja je mogućnost - rijetko potvrđena u promatranom korpusu - genitivni nastavak u akuzativu za živo bez promjene paradigmatske pripadnosti, kao u (21):22

(21) A jd.: v'spomenu abraama patriêrhi i sarru ženu ego BrLab 178b

U hrvatskom se crkvenoslavenskom jeziku kategorija živosti stala širiti i u dvojinu i množinu, ali je u tim okolinama tek u začetku pa još nije zahvatila imenice (j)a-deklinacije. Drukčije je u staroj čakavštini, ${ }^{23}$ u kojoj ćemo se susresti i s ovakvim primjerima genitivno-akuzativnoga sinkretizma (oba su primjera iz Lekcionara Bernardina Splićanina):

(22) A mn.: skazujmo nas samih kakono slug božjih

(23) A mn.: i on jest dal stanovito nicih apostolof, nicih prorokof, a druzih evangelist, a jinih pastirof i učitelef

Posljednji nas primjer već uvodi u sljedeći odjeljak, koji govori o miješanju (j)a-deklinacije i (j) o-deklinacije, jer oblik evanjelistb u hrvatskom crkvenoslavenskom pripada objema (24). Za starohrvatski je primjerenije genitivni oblik za akuzativ množine evangelist uvrstiti u (j)a-deklinaciju jer jedino tom obliku manjka pokazatelj (j)o-sklonidbe: -ov-/-ev- (usp. A mn.: apostolof, prorokof, pastirof, učitelef evangelist).

\section{Alterniranje s oblicima (j)o-deklinacije}

Za niz imenica moramo pri uspostavljanju paradigme predvidjeti dva mjesta: jedno među (j)a-osnovama, drugo među (j)o-osnovama. Takvu dvojaku pripadnost zorno će nam dočarati primjeri u kojima se isti tekst, posvjedočen u više hrvatskoglagoljskih liturgijskih spomenika, odlikuje različitim odabirom padežnih nastavaka za imenice muškoga roda:

(24) N jd: e(van)j)(e)/(i)sta iv(a)n’ v svoei e(pisto)lii gl(agole)tb / evanjelistb BrAc 42c

(25) G jd.: k' ezekielû pr(o)r(o)ku s(i)nu bozie erêê BrVO 431b / boziê BrN $249 \mathrm{~b}$

(26) G jd: spomenutie sv(eta)go pavla prvago remeta MVat $16 \mathrm{~d} /$ rem(e)ti MLab 16d

(27) D jd.: povese û k' al'mahiû sudii BrLab 158a / al'mahii BrVat $203 d$

(28) D jd:: sl(o)vo g(ospodn)e eže stvoreno estb k' osii BrN 2 353d / osiû BrVat ${ }_{5} 234 \mathrm{C}$

21 O takvom ostvaraju kategorije živosti izvješćuje proučavatelj omišaljskoga govora, ističući činjenicu važnu za našu temu, naime: "Kod imenica na -a koje nisu ženskog roda pojava je raširenija. U Omišlju je nalazimo kod imenica muškog roda na -ina, npr. Asg. Maletini, podeganini, vražini (-i je nastavak Gsg.)" (Vermeer 1984: 275). Neobičnu morfosintaktičku pojavu - uvjetovanu fonološkim razlozima - poznaju neki govori Buzeštine. Tamo sve imenice (j)a-deklinacije - ne samo muškoga roda, nego i ženskoga - te njihovi atributi u akuzativu jednine dobivaju genitivni nastavak ako označuju živo (Ribarić 2002: 42; Vince Marinac 1990: 145; Vince 2005: 106). Razliku između muškoga i ženskoga roda i tu prenose pridjevi i zamjenice. Stoga u tim govorima za imenice (j)a-deklinacije moramo pretpostaviti čak tri sročnosna razreda!

22 Ima i suvremenih čakavskih govora s bogato (i raznoliko!) potvrđenim izricanjem živosti. Usp. VERMEER 1984.; Vince Marinac 1990; 1992. te tamo navedenu literaturu. Na djelu su dvije pravilnosti: imenice (j)a-deklinacije neće razviti genitivno-akuzativni sinkretizam prije nego što je on zaživio u imenica (j)o-deklinacije (prvo A mn. učenik, a onda A mn. slug), a muški rod podložniji je uvođenju kategorije živosti nego ženski (A mn. žen tek nakon A mn. slug). Redoslijed je postanka genitivnih oblika za akuzativ, prema tome, pretkažljiv: učenik > slug > žen. To je zato što je sluga i sl. u množini promjenjiva roda.

23 Nastavak -omь za I jd., kao u primjeru: iûnu pr(o)r(o)kom’ BrVO 161d / iûnom’ BrPm 78d ne ukazuje na pripadnost imenice o-sklonidbi jer i imenice ženskoga roda a-deklinacije katkada dobivaju taj nastavak - koji se u suvremenom hrvatskom u obliku -om proširio na sve imenice (j)a-deklinacije. 
(29) D jd.: sudiû kvirinu preporučens bê BrN 496d / sudii BrLab 117c

(30) A jd.: al'mahiû sudiê ponižaûĉi BrLab 156a / sudiû BrVat $202 c$

(31) V mn.: vsi s(ve)ti patriêr'he i pr(o)r(o)ci CPar 139v / patriêrsi BrN $2496 \mathrm{~d}$

Za više potvrda kolebanja između nekih oblikâ (j)a-deklinacije i (j)o-deklinacije ipak sam morala posegnuti za različitim tekstovima, s različitim padežima: 24

(32) G jd:: sl(o)v(e)sa eremie pr(o)roka BrVO 208a

(33) I jd.: rečeno est' eremiem' pr(o)rokom' BrVO 56d

(34) N jd.: sta že ezdra knigočiê na odrê drêvenê MVat 4 148cd

(35) D mn.: rêše ezdrê knigočiû MVat $4148 \mathrm{c}$

\section{Posvojni pridjevi}

Imamo li na umu da se od imenica muškoga roda s (j)o-osnovom posvojni pridjevi tvore s pomoću sufiksa -ov-/-ev- te da je za imenice (j)a-deklinacije taj sufiks -in- bez obzira na rod, tada očekujemo da će se od imenica muškoga roda s dvostrukom paradigmom posvojni pridjevi graditi čas na jedan, čas na drugi način. ${ }^{25}$ Kada bi se sve završilo na tome, spomenutim pridjevima i ne bi bilo mjesta u radu koji promatra nepodudarnosti između muškoga i ženskoga roda u imenicâ (j)a-deklinacije. Osebujnost se muškoga roda sastoji u pojavi pridjevnoga sufiksa -ov- (iûdovb, iûnovb) usporedno sa sufiksom -in- (iûdinb, iûninb) i onda kada same imenice - od kojih je prva obilno potvrđena u građi - nedvosmisleno iskazuju pripadnost samo a-deklinaciji:26 iûda i iûna. ${ }^{27}$ Kao varijanta uz pridjeve iûdovb i iûdinı nastupa pridjev iûdêiskь:

(37) G jd:: s(i)na ozie c(êsa)ra iûdêiska BrVO 19b / iûdova BrVat $_{5} 8 c$

(38) G mn:: c(êsa)rı iûdêiskihı BrVat ${ }_{5} 235 d$ / iûdinı BrVO 415d

(39) L jd.: pokaêše se v propovêdi iûnovê MVat 32 d

(40) A jd:: prirazi sl(b)nce na glavu iûninu BrVO 456a

\section{Homonimija}

Imenice muškoga roda (j)a-deklinacije unose "nered" u sustav time što se - bez obzira na "mušku sklonidbu" pripadajućih im pridjeva - same sklanjaju poput pridjeva ženskoga roda. Nije stoga neobično što se takve osnove često "sele" u (j)o-sklonidbu (v. 4. odjeljak). Pravi problem može nastati onda kada se imenice (j)a-deklinacije odnose i na muško i na žensko. U parovima bližika m./f. i užika m./f. koji su nam se predstavili u primjerima (8), (9) i (10) nije bilo poteškoća u pripisivanju roda zahvaljujući sročnosti između imenice i (pridjevne) zamjenice i/ili apoziciji koja donosi obavijest o spolu referenta. Takvi su i ovi primjeri:

(41) D jd.: ti gl(agol)i k ûnošici onomu BrN 2 260b

(42) I jd.: sa eteroû ûnošiceû BrVat $677 \mathrm{~b}$

\footnotetext{
24 Pregršt primjera donosi Sudec (2010: 64).

25 Poznato je da se od imenica (j)a-deklinacije koje ne označuju osobu (riječ je, dakako, o imenicama ženskoga roda) pridjevi slobodno tvore s pomoću sufiksa -ov-, ali on tada nema posvojno značenje (usp. hrv. lipov čaj, maslinovo ulje, vrbovo pruće). U hrvatskocrkvenoslavenskome korpusu Sudec (2010: 54-55) pronalazi takve tvorbe od toponima: golgotovь i kalvarievb, a od naziva za biljke i životinje - maslina i ehinda - po dvije inačice: maslinovь i maslinınovь te ehidnovь i ehindovь. Budući da iûda ne označuje samo (mušku) osobu nego i zemlju, moguće je i takvo objašnjnje po kojem bi se oblik iûdovb odnosio na ovo posljednje. Iznimno se uz pomoć sufiksa -ov- tvore posvojni pridjevi i od vlastitih ženskih imena s (j)a-osnovom: agarovb, naneovb / nan(e)evb ali oni se smatraju prevoditeljskom pogreškom (Sudec 2010: 55).
}

26 O imenici iûna v. bilj. 24.

27 Usp. bilj. 21. 
U (43) je iz ostatka rečenice jasno da se govori o ženi, a u (44) je muški rod razabirljiv tek iz širega konteksta:

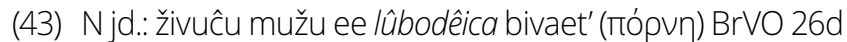

(44) D mn.: ne primêšati se k lûbodêicam'(пópvos) BrVO 105c

Imenice vladika ${ }^{1}$ m. i vladika² f. drukčiji su homonimi jer se razlika u značenju među njima ne svodi bez ostatka na razliku u spolu. Na koncu, u obliku an'na stopila su se dva posve različita imena - muško i žensko. Sve je to razvidno i iz latinskih varijanata:

(45) A jd:: posla nenavistnago vladiku apoloniê BrVO 430d (princeps)

(46) A mn.: stvori vladiki mužate i d(ê)vi tihe kb mnê po trihı d'nehь priti BrN 2 424d (matrona)

(47) D jd.: êše i(su)sa i svezavše i i privêse i kb an'nê MVat 4 90d (Annas m.)

(48) A jd.: poêtb ženu ot kolêne svoego imenemb an'nu BrVO 380d (Anna f.)

\section{Padež zanijekanoga izravnoga objekta}

Smjenjivanju akuzativa i genitiva kao izravnih objekata zanijekanoga glagola posvećeno je mnogo radova. I sama sam se pozabavila tim složenim pitanjem uspoređujući hrvatski crkvenoslavenski sa starohrvatskim (Vince Marinac 1998, Vince 2008). Kada se s nekom sintaktičkom pojavom susrećemo samo u određenim okolinama, to je znak da je ona u previranju: zato što je tek u nastajanju, ili se, naprotiv, gubi. Nameće se stoga potreba za opisom tih okolina. U važnom radu posvećenom genitivu uz negaciju, među čimbenicima koji pogoduju "uzmaku" genitiva izravnoga objekta u tablici se navodi i jedna morfološke naravi: pripadnost (j)a-deklinaciji - i to u jednini (Timberlake 1986: 356) - dok drugi autor - koji se također bavi padežom zanijekanoga objekta - te imenice obrađuje u poglavlju naslovljenom: Nouns Ending in -a, -ja (Restan 1960: 95). Ustanovljeno je da su imenice (j)a-sklonidbe u zanijekanim rečenicama podložnije zamjeni genitiva akuzativom od ostalih. To su one iste imenice za koje je utvrđeno da su "najotpornije" na uvođenje genitivnoga nastavka u sintaktički akuzativ (Klenin 1983: 106). ${ }^{28}$ Kada je riječ o našoj građi, možemo izvijestiti da se ta zakonitost i u njoj potvrdila. ${ }^{29}$

Dosad se u ovom odjeljku o imenicama (j)a-deklinacije govorilo bez obzira na njihovu rodnu pripadnost. Primjer iz 29. bilješke pokazao je kako je akuzativ vjerojatniji u toj nego u drugim paradigmama (G jd. zla, ali A jd. klevetu). Starohrvatski primjer u nastavku otkriva nešto novo, za našu temu ključno: čak i onda kada se imenice (j)a-deklinacije ženskoga roda slažu s ostalim imenicama u čuvanju genitiva izravnoga objekta, imenice iste paradigme - ali različite rodne pripadnosti - već nalazimo u akuzativu (G jd. žene ńegove, rabe ńegove prema A jd. slugu ńegova iz Lekcionara Bernardina Splićanina):

(49) G jd. / A jd.: ne poželi žene ńegove, ne poželi slugu ńegova, ne poželi rabe ńegove, ne poželi vola ni poslenika ni nijedne stvari ńegove

Čimbenik kojim to objašnjavamo jest, dakako, muški rod. Timberlake ga, doduše, ne navodi, ali nam je poznat iz opisa jedne druge morfosintaktičke pojave - izricanja živosti pomoću genitiva za akuzativ (Klenin 1983: 106).

\section{Vokativ}

Uzeti u cijelosti, tekstovi pisani hrvatskim crkvenoslavenskim jezikom u jednini dobro razlikuju vokativ od nominativa tamo gdje im stoji na raspolaganju poseban oblik za taj padež, ali katka-

28 Usp. bilj. 21.

29 "[P]ripadnost toj paradigmi - koja se odlikuje morfološkom obosobljenosti (Timberlake 1986: 353) - "poništava" katkada genitiv, što dokazuje inačica iz Hrv (zla : klevetu) u sljedećem primjeru:

1P 3,9 ne vzdajuĉe zla za zlo ni klevetu za klevetu (...)" (Vince 2008: 619). 
da ćemo se susresti i s vokativom jednakim nominativu. Usporedba imenica muškoga i ženskoga roda (j)a-deklinacije otkrit će nam dvije pravilnosti u uporabi vokativa. Prva je statističke naravi. S obzirom na broj osnova u prvoj i drugoj promatranoj skupini, vokativ je razmjerno bolje zastupljen u prvoj, a jasno je i zašto: te su imenice semantički pogodnije za uporabu toga padeža jer sve odreda imenuju osobe, što za one ženskoga roda ne stoji. S druge strane, vokativ kao kategoriju bolje čuvaju imenice ženskoga roda. Temeljito proučivši jezik hrvatskoglagoljskoga rituala Tandarić je utvrdio da "Vsg. vlastitih imena na -a ima različit nastavak prema tome odnosi li se na muške ili na ženske osobe: sveti Luka, sveti Barnaba - sveta Agato, sveta Klaro i dr." (Tandarić 1993: 98). To ne znači da u širem korpusu u muškom rodu nećemo naći i suprotnih primjera (lijevo je nominativ, a desno vokativ):

(50) N jd., V jd.: bê že eterъ učenikъ vъ damascê ïmenemъ ananiê ï reče k nemu gospodъ vъ snê ananie FgGrš 4v / ananiê... ananiê MVat ${ }_{4} 174 \mathrm{C}$

\section{Završna napomena}

Iz svega iznesenoga razvidno je da su imenice muškoga roda (j)a-deklinacije u hrvatskom crkvenoslavenskom jeziku doista zasebna skupina. One se od ostalih imenica iste deklinacije razlikuju po semantičkom rodu, ali i živosti, koja se sintaktički očituje u genitivnom obliku za akuzativ u pridjeva i nekih zamjenica sročnih s tim imenicama. Kao objekti te su imenice sklonije zamjeni genitiva akuzativom, a vokativ im je oblikom češće izjednačen s nominativom nego što je to slučaj u imenica ženskoga roda iste sklonidbe. Katkada od imenica ženskoga roda (j)a-deklinacije odstupaju i posebnom morfologijom koja in pak približava imenicama muškoga roda (j)o-deklinacije jer od njih "posuđuju" oblike. S imenicama (j)o-deklinacije povezuje in i sročnost po rodu i živosti, samo što u imenicâ muškoga roda (j)a-deklinacije ima i kolebanja u sročnosti. Najzanimljiviji je posljedak sročnosti po obliku seoba imenica iz muškoga roda (u jednini) u ženski (u množini i dvojini); usp. N jd. vašb susêdb, voevoda vaša pobêda; N mn. vaši susêdi vaše voevodi, pobêdi i N dv. vaša susêda vaši voevodê, pobêdê). 


\section{POPIS LITERATURE}

BABIĆ 1984

Stjepan Babić, Sročnost u hrvatskome književnome jeziku, Zagreb 1984.

\section{CEJTLIN 1997}

Ralja Mihajlovna Cejtlin, Leksika staroslavjanskogo jazyka, Moskva 1997.

\section{CORBETT 1988}

Greville G. Corbett, "Gender in Slavonic from the Standpoint of a General Typology of Gender Systems", The Slavonic and East European Review, 66, London 1988., 1-20.

\section{DAMJANOVIĆ 2005}

Stjepan Damjanović, Staroslavenski jezik, Zagreb 2005.

\section{GLAVAN 1928-29}

Vjenceslav Glavan, "Kongruencija u jeziku starih čakavskih pisaca", Južnoslovenski filolog, 7, Beograd 1928.-29., 111-159.

\section{IVIĆ 1968}

Milka Ivić, "Obeležavanje imeničkog roda u (standardnom) slovenačkom jeziku upoređeno s odgovarajućom srpskohrvatskom situacijom", Zbornik za filologiju i lingvistiku, 11, Novi Sad 1968., 49-55.

\section{KLENIN 1983}

Emily Klenin, Animacy in Russian: A New Interpretation, Columbus 1983.

\section{MARETIĆ 1885}

Tomo Maretić, "Lekcionarij Bernardina Spljećanina po prvom izdanju od god. 1495.", Djela JAZU, 5, Zagreb 1885., 1-208.

\section{MIHALJEVIĆ 2004}

Milan Mihaljević, "Deklinacija imenica u najstarijim hrvatskoglagoljskim fragmentima", u: Glagoljica i hrvatski glagolizam, Zbornik radova s međunarodnoga znanstvenog skupa povodom 100. obljetnice Staroslavenske akademije i 50. obljetnice Staroslavenskog instituta, (ur. MarijaAna Dürrigl, Milan Mihaljević, Franjo Velčić), Zagreb, Krk: 2004., 625-636.

\section{MIHALJEVIĆ 2011}

Milan Mihaljević, "Bilješke o jeziku 2. beramskog brevijara", Tabula 9.

\section{NAYLOR 1988}

Kenneth E, "The Relationship of Gender and Declension in the Slavic Substantive", u: American Contributions to the Tenth International Congress of Slavists (Sofia, 1988), 1, Linguistics (ur. Alexander M. Schenker), Columbus 1988., 532-551.

\section{RESTAN 1960}

Per A. Restan, "The Objective Case in Negative Clauses in Russian", Scando-Slavica, 6, Copenhagen 1960., 92-112.

\section{REŠETAR 1894}

Milan Rešetar, "Zadarski i Rańinin lekcionar", Djela JAZU, 13, Zagreb 1894., 1-330.

\section{RIBARIĆ 2002}

Josip Ribarić, O istarskim govorima, Pazin 2002.

\section{RJEČNIK 2000}

Rječnik crkvenoslavenskoga jezika hrvatske redakcije, l: a - vrêdb, (ur. †Biserka Grabar, Zoe Hauptová, †Franjo Većeslav Mareš), Zagreb 2000.

\section{SLOVNIK 1959-1997}

Slovník jazyka staroslověnského (ur. Josef Kurz et al.), Praha 1959.-1997.

\section{SUDEC 2009}

Sandra Sudec, "Imenice izvedene sufiksom -čii u hrvatskoglagoljskim tekstovima", Slovo, 59, Zagreb 2009., 151-165.

\section{SUDEC 2010}

Sandra Sudec, Tvorba pridjeva u hrvatskome crkvenoslavenskome jeziku (doktorska disertacija u rukopisu), Zagreb 2010.

\section{TAFRA 2005}

Branka Tafra, Od riječi do rječnika, Zagreb 2005.

\section{TANDARIĆ 1993}

Josip Tandarić, Hrvatskog/agoljska liturgijska književnost, Zagreb 1993.

\section{TIMBERLAKE 1986}

Alan Timberlake, "Hierarchies in the Genitive of Negation", u: Case in Slavic (ur. Richard D. Brecht, James S. Levine), Columbus 1986., 338-360. 


\section{VERMEER 1984}

Willem Vermeer, "Opozicija tipa 'živo/neživo' u množini u jednom čakavskom sistemu (Omišalj)", Naučni sastanak slavista u Vukove dane. Referati i saopštenja, 13, Beograd 1984., 275-288.

\section{VINCE 2004}

Jasna Vince, "Uz morfosintaktičke teme u Ribarićevu opisu istarskih dijalekata", Buzetski zbornik, 30, Buzet 2004., 103-109.

\section{VINCE 2008}

Jasna Vince, "Uzmak genitiva izravnoga objekta", Slovo, 56-57, Zagreb 2008, 615-626.

\section{VINCE MARINAC 1990}

Jasna Vince Marinac, "Kategorija živosti u hrvatskom jeziku", Suvremena lingvistika, 29-30, Zagreb 1990., 143-152.

\section{VINCE MARINAC 1992}

Jasna Vince Marinac, "Vrste riječi i genitivnoakuzativni sinkretizam", Suvremena lingvistika, 34, Zagreb 1992., 331-337.

\section{VINCE MARINAC 1992-93}

Jasna Vince Marinac, "Predikatni proširak u akuzativu: Čimbenici koji uvjetuju genitivni oblik za akuzativ", Croatica, 37/38/39, Zagreb 1992.-93., 387-398.

\section{VINCE MARINAC 1998}

Jasna Vince Marinac, Akuzativ u hrvatskom crkvenoslavenskom jeziku (doktorska disertacija u rukopisu), Zagreb 1998.

\section{ZIMA 1887}

Luka Zima, "Ńekoje, većinom sintaktične razlike između čakavštine, kajkavštine i

štokavštine", Djela JAZU, 7, Zagreb 1887., 1-342.

\section{MASCULINE (j)a-DECLENSION NOUNS IN CROATIAN CHURCH SLAVONIC AND OLD CROATIAN}

The aim of the paper is to point to morphological, syntactic and semantic peculiarities of masculine (j)a-declension nouns in Croatian Church Slavonic and Old Croatian. In contrast to other (j)a-declension nouns the nouns described allways indicate males. It is therefore not surprising to find nouns with both (j) 0 - and (j)a-declension desinences. Diversity in noun-adjective congruity and possessive adjective forming is noted. The role of masculine gender in case assignment (accusative vs. genitive in direct objects of negated verbs) and nominative-vocative syncretism in singular within (j)a-declension are also discussed.

Key words: Croatian Church Slavonic, Old Croatian, (j)a-declension, masculine gender, congruity, morphology, syntax, semantics 